\title{
LANDSLIDE SUSCEPTIBILITY MAPPING BY GIS-BASED QUALITATIVE WEIGHTING PROCEDURE IN CORINTH AREA
}

\author{
Foumelis M. ${ }^{1}$, Lekkas E. ${ }^{1}$, Parcharidis I. ${ }^{2}$ \\ ${ }^{1}$ Department of Dynamic Tectonic \& Applied Geology, Faculty of Geology, University of Athens, \\ mfoum@geol.uoa.gr, elekkas@geol.uoa.gr \\ 2 Space Application Research Unit, Department of Geophysics-Geothermics, Faculty of Geology, \\ University of Athens, parchar@geol.uoa.gr
}

\section{ABSTRACT}

Landslide susceptibility mapping refers to a division of the land into zones of varying degree of stability based on an estimated significance of causative factors in inducing the instability. Maps of landslide susceptibility (relative hazard) are usually prepared on regional scales from 1:25.000 1:50.000. An advantage of regional studies is that they allow rapid assessment and hence larger areas can be covered in short durations.

Factors (data layers) used for the preparation of the landslide susceptibility map were obtained from different sources such as topographic maps, geological maps and satellite images. All the above data layers were converted to raster format in the GIS, each representing an independent variable of a constructed spatial database. Computerization of the database would be necessary to make such analysis possible within an acceptable time frame.

According to their relative importance to slope instability in the study area, the various classes of different data layers were assigned weights between 0,0 and 1,0 (collectively adding to 1,0 ). The overall susceptibility was calculated as an index named SPI (Susceptibility Potential Index), expressing the combination of the different weighted layers into a single map using a certain combination rule. Reclassification of susceptibility scores, based on natural breaks in the cumulative frequency histogram of SPI values, were used to delineate various susceptibility zones namely, very high, high, moderate, low and very low.

Verification of results by overlaying susceptibility map and landslide inventory data and adjustment of zone's boundaries was the last stage of the study, allowing the reconsideration in some cases of the weights given.

\section{INTRODUCTION}

The present study is aimed to examine further the integration of terrain data in landslide analyses and to contribute to the recognition of areas of possible environmental degradation. The location chosen for the study was Corinth, which repeatedly suffered by landslides following heavy rainfalls (Fig. 1). Our main focus was on Xerias River basin, the largest drainage catchment in the NE of Peloponnese. The entire area is characterized by complex geology, active tectonics - seismicity and occasional heavy rainfalls of high intensity. Their influence on natural hazards, including landslides (ground mass movements) is significant.

Small-scale regional surveys are used by planning agencies for preliminary planning - feasibility studies - of infrastructural works (e.g. the definition of road corridors), when an economical and rapid hazard assessment technique is required. In such techniques a direct relationship is made between the occurrence of slope failure and the causative terrain parameter.

While the process and the exact mechanism of landslide initiation are difficult to be well understood due to mutual interaction of various factors, previous studies combining field observations, statistical analysis and GIS techniques have shown that several factors were found to have significant influence on slope stability (Gokceoglu \& Aksoy 1996, Lee \& Min 2001, Saha et al. 2002). 
With the advent of remote sensing and geographic information systems (GIS) technology, it has become possible to efficiently collect, manipulate and integrate a variety of spatial data. GIS has proved to be an excellent tool in the spatial analysis of terrain parameters for landslide susceptibility zonation.

\section{BACKGROUND}

Slope instability hazard zonation is defined as the mapping of areas with an equal probability of occurrence of landslides within a specific period of time (Varnes 1984), while susceptibility mapping depicts division of land surface into zones of varying degree of stability based on the estimated significance of the causative factors in including the instability (Anabalagan 1992). Thus susceptibility should be examined as the likelihood that such phenomena occurs under the given terrain conditions regardless of the time scale (time-recurrence) within which a particular landslide is likely to take place (van Westen et al. 1997, Atkinson \& Massari 1998). The susceptibility term also does not depend on impact factors such as rainfall, earthquake and human activity (Lee \& Min 2001). In this case study the probability of occurrence of slope movement is not considered, nor the triggering mechanisms.

Although knowledge on the causes of landslides is essential in decision making, the occurrence of slope instability is highly correlated with intrinsic variables that contribute to the occurrence of landslides, such as geology, land cover, slope gradient etc. The spatial distribution of in-

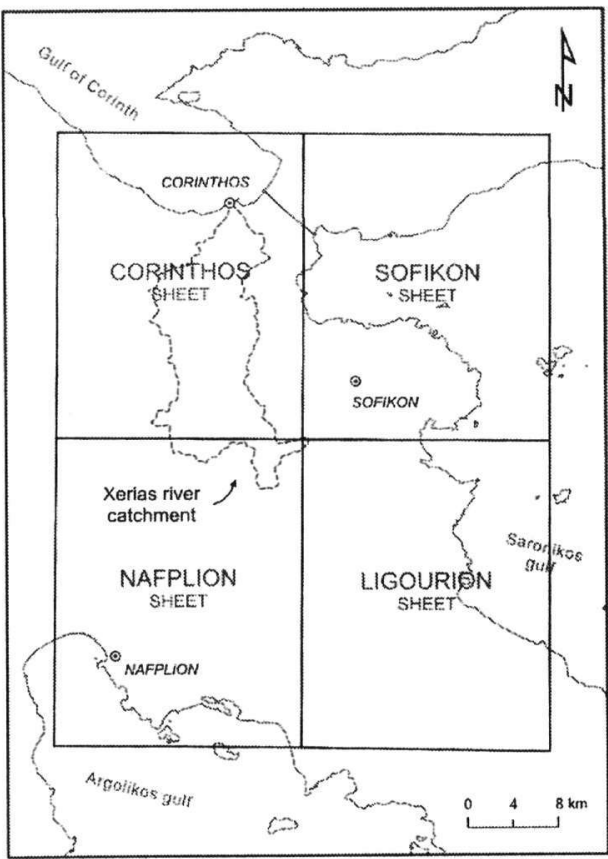

Figure 1. Location of the study area. trinsic variables within the study area determines the spatial distribution of relative landslide susceptibility in that region (Carrara et al. 1995). The idea is to identify the critical combination of site conditions that are capable to induce mass movements and to map areas in which such combinations are present.

When making use of GIS techniques, different methodological approaches can be followed. Many techniques have been proposed relating geological and geomorphological factors in an effort for the recognition of areas of probable landsliding (Carrara et al. 1991, van Westen 1993, Gokceoglu \& Aksoy 1996, Pachauri et al. 1998, Donati \& Turrini 2002). Qualitative approaches are particularly suited for small-scale regional surveys. An a priori knowledge on the causes of landslides is essential as a direct relationship is made between the occurrence of slope failure and the causative terrain parameters.

Systematically collected data are analyzed in a GIS context that offers an easy way to establish weight factors for the variables. In practice the methodology is essentially the same as the conventional techniques in the assessment of slope stability at regional scale, with the advantage that GIS offers the possibility for weighting of factors together with easy display of slight modifications in the decision rules and the comparison of the results with the conception of the expert. The relationship between landslides and their geomorphic and geologic setting - eventually the degree of susceptibility - is determined by the geologist based on his/her experience and knowledge of the terrain conditions (van Westen 1999). In an iterative process the optimization of the susceptibility map is positive as long as the quality of the input data is good and sufficient knowledge exits on the combination of various factors in relation to the occurrence of landslides. Thus site visits were undertaken to confirm and complete information. 


\section{CONSTRUCTION OF SPATIAL GEODATABASE}

The importance of defining independent variables that reflect conditions prior to slope movements should be addressed (Atkinson \& Massari 1998). Factors were selected according to the scale upon which the study is applied (Fig. 2).

The factors used for the preparation of landslide susceptibility map were obtained from topographic sheets of the Hellenic Military Geographical Service - HMGS, geological maps of the Institute of Geological \& Mineral Exploration - IGME (Tataris et al. 1970, Bornavas et al., 1971, Bannert, 1981, Gaitanakis et al. 1985) and soil maps of the Ministry of Agriculture - MoA (Vardakis et al. 1985, 1988, Lakaphossi et al. 1987, Schinas et al. 1987). The collected maps (Fig. 1) were at the same scale (1:50.000). Also satellite imagery (a Landsat $7 \mathrm{ETM}+$ scene) was used to delineate lineaments - possible faults and to extract terrain properties related to land cover. A grid-based Digital Elevation Model (DEM) representing the earth's surface was prepared by interpolating the already digitized contour lines and hypsometric points of the topographic sheets of HMGS. The rubber sheet technique was used for interpolation of heights. To test the accuracy of the DEM a contouring procedure was followed and a comparison is been made between the primary contour lines and the modeled ones. The comparison shows satisfactory results, ensuring the quality of the subsequent analysis as many of the factors affecting landslide susceptibility were to be generated from the DEM. Factors chosen for the estimation of landslide susceptibility in the study area are briefly described below. All the mentioned thematic layers were georeferenced to the Greek Geodetic Reference System (GGRS'87).

\section{Geology [GEO]}

Geology is one of the most important factor controlling landslides. Several researchers (Koukis \& Ziourkas 1991, Nikolaou 1997) emphasized the role of geology on the stability of slopes. These statistical analyses together with field observations were used to assess the weightings of different formations towards landslide susceptibility. The geological maps was transformed into a digital form by simple digitization. The majority of the study area is covered by limestones $(37,8 \%)$, Neogene sediments (39,6\% - mainly marls) and Quaternary loose deposits $(21,3 \%)$.

\section{Land cover [LC]}

The presence or absence of vegetation may affect landslide susceptibility. Dense vegetation cover reduces the availability of water by intercepting the rainfall and as a consequence of absorption and evapotranspiration. Land may be more or less subject to erosion in relation to vegetation type. Root systems (especially those of woody areas) increase the shear strength of soil through mechanical action and suction within the soil and help to improve the stability of slopes.

Known training sets representing recognized in the field land cover types were evaluated for seperability using transformed divergence. ETM bands 2, 4 and 7 (RGB - 472) were found to provide the greatest overall seperability between various land cover classes.

In order to improve the spatial resolution of Landsat 7 ETM+ multispectral data a fusion technique was applied using as high resolution image the corresponding panchromatic scene $(15 \mathrm{~m} /$ pixel). For the transformation the IHS - RGB - IHS method was selected (Carper et al. 1990).

For the production of land cover map a Landsat 7 ETM+ scene was classified using the supervised Maximum Likelihood Classifier (MLC). Post-classification filtering was carried-out to remove high frequency variations (ERDAS, 2002).

\section{Slope gradient [SL]}

Slope has multiple influence on the landslide susceptibility. It directly effects on shear stress in soils - unconsolidated materials - and indirectly controls surface water velocity (degree of saturation). Gentle slope - low gradients are expected to have lower susceptibility to landsliding than steep ones. Slope gradient was modeled by Horn's method (Horn, 1981) using a grid-based DEM. As the first derivative of elevation slope gradient was derived by calculating the maximum rate of change in elevation from a center cell to its eight neighbors. The method takes into considerationthe local variability of terrain and applies weights to each of the neighboring cells according to the distance from the center cell (transverse cells are given higher weights than the diagonal ones). 


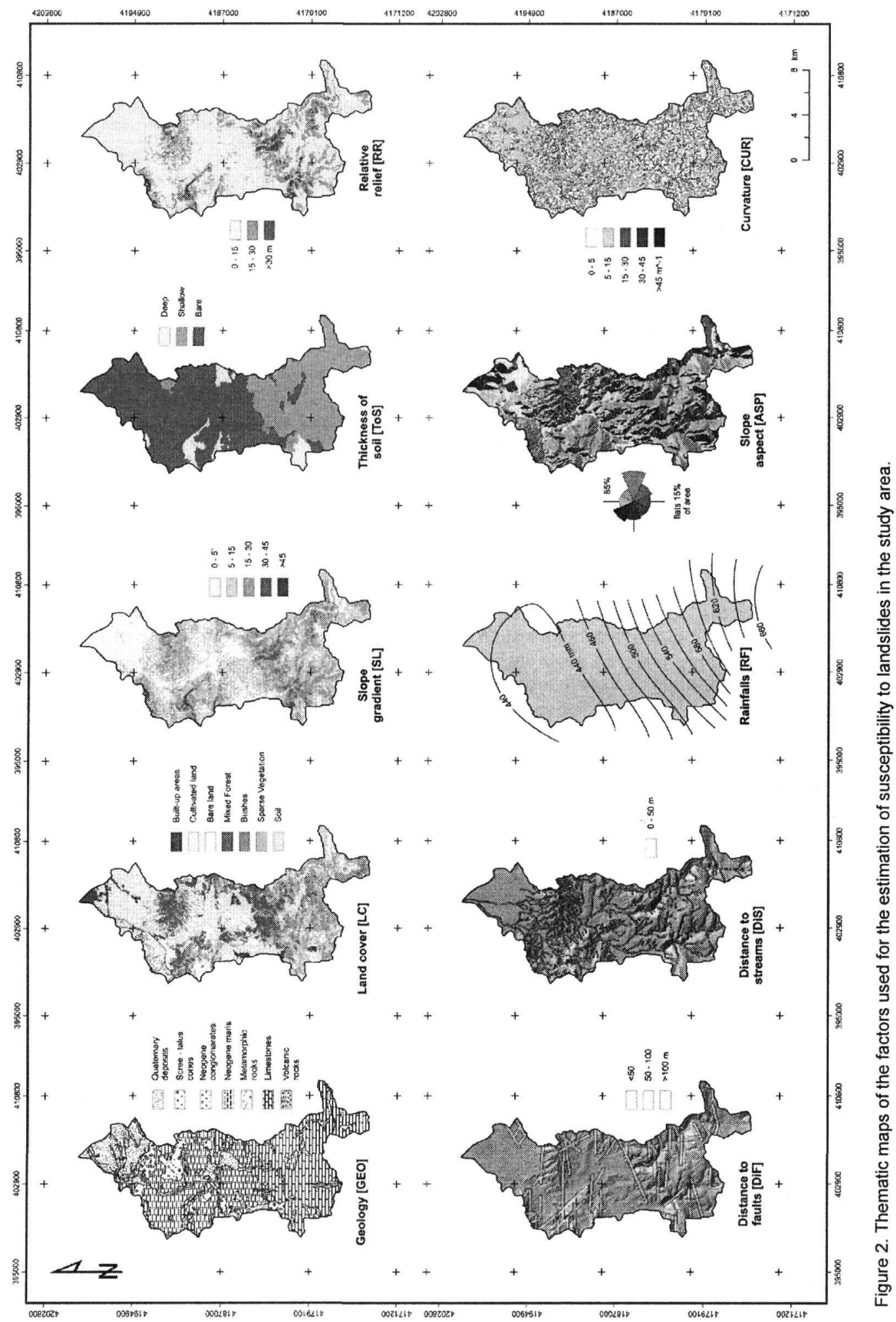




\section{Thickness of soil [ToS]}

Thickness of soil affects the rate of infiltration and the nature of slope movement. Soil maps of MoA was acquired and digitized. The information regarding soil thickness was already classified into three categories namely deep, shallow and bare. These classes were used to reflect the importance of soil thickness towards landslide susceptibility .

\section{Relative relief [RR]}

Relative relief portrays the absolute maximum difference in elevation at a specific point, calculated in a $5 \times 5$ matrix of cells. For slopes with identical geomechanical and geometrical parameters except for height, the higher elevation difference will be more susceptible to landslide. In such topography higher runoff and lower infiltration is expected (Singh, 1989).

\section{Distance to faults [DiF]}

Faults form a line or zone of weakness characterized by heavily fractured rocks. Distance (buffers) from tectonic structures features as likelihood of occurrence of landslides. Selective erosion and movement of water along fault planes promote such phenomena. Besides the major thrusts and faults in the geological maps complementary information regarding possible faults and structural dislocations were recognized as lineaments by means of image enhancement (filtering) of satellite imagery. From the implemented edge enhancement and detection filters the most promising was the non-directional $3 \times 3$ Prewitt filter and the high pass $5 \times 5$ filter. The recognition of lineaments - possible faults was made step-by-step form large to smaller scales allowing the generalization of many neighboring small order lineaments taking into account the spatial scale of the study.

\section{Distance to streams [DiS]}

Some studies showed that proximity to drainage lines of intensive gully erosion is an important factor controlling the occurrence of landslides (Gokceoglu \& Aksoy 1996, Pachauri et al. 1998). This can be attributed to the fact that terrain modification caused by gully erosion (undercutting action of streams) by may influence the initiation of landslide. Also maximum infiltration is observed on slopes adjacent to streams where the materials have maximum permeability, i.e. fragmented rock/colluvial deposits. Drainage lines were derived directly from the topographic sheets and distances (in meters) from them were calculated in the form of buffers around the vector datasets.

\section{Rainfalls [RF]}

The consideration of this factor was based on the assumption that wet conditions are more likely to occur at areas of higher mean areal rainfall. Monthly rainfall data was collected from the Hellenic National Meteorological Service - HNMS, the Ministry of Agriculture - MoA and the Ministry of Public Works - MPW. Before any interpretation rainfall data were adjusted and breaks were completed by linear regression techniques (Singh, 1989). Spatial variability of rainfalls over the study area was explored by interpolating data from seven meteorological stations using Splines technique. The above technique was found to be the most suitable as rainfall data representing variability of rainfalls over a period of 30 years was expected to be somehow smooth at the specified spatial scale.

\section{Slope aspect [ASP]}

The degree of saturation of slope forming material has significant control over the occurrence of landslides. Previous studies have shown that landslides are usually abundant on N, NNE and SSW orientations a fact that was attributed mainly to climatic factors (Koukis et al. 1994).

\section{Curvature [CUR]}

Curvature represents practically the morphology of the topography (Zevenbergen \& Thorne, 1987). Positive values indicate upwardly convex surface at that cell and negative values surface that is upwardly concave. A value of zero represents flat areas. For negative values the lower the value the higher the landslide susceptibility. Following heavy rainfall upwardly concave slopes have more water and retains it longer. Upwardly convex areas show no correlation with landslide occurrence. 


\section{WEIGHTING OF FACTORS}

All the mentioned above data layers were converted to raster format in the GIS, each representing an independent variable of a constructed spatial database. Computerization of the database would be necessary to make such analysis possible within an acceptable time frame.

Table 1. Established weight system and relative significance of various factors to landslide susceptibility.

\begin{tabular}{|c|c|c|c|c|}
\hline Data Layer (Factor) & Class & $\begin{array}{c}\text { Class value } \\
\text { (Rating) }\end{array}$ & Weighting & Significance \\
\hline \multirow[t]{6}{*}{ Geology [GEO] } & Volcanic rocks & 1 & 0,10 & 0,10 \\
\hline & Limestones & 2 & & 0,20 \\
\hline & Metamorphic rocks & 3 & & 0,30 \\
\hline & Quaternary deposits & 4 & & 0,30 \\
\hline & Neogene sediments & 5 & & 0,40 \\
\hline & Scree - Talus cones & 6 & & 0,60 \\
\hline \multirow[t]{8}{*}{ Land Cover [LC] } & Mixed forest (MF) & 1 & 0,10 & 0,10 \\
\hline & Bushes (B) & 2 & & 0,20 \\
\hline & Sparse vegetation (SV) & 2 & & 0,20 \\
\hline & Grassland $(G)$ & 3 & & 0,30 \\
\hline & Cultivated land (CL) & 4 & & 0,40 \\
\hline & Soils (S) & 5 & & 0,50 \\
\hline & Build-up areas (BA) & 5 & & 0,50 \\
\hline & Bare land $(\mathrm{BL})$ & 6 & & 0,60 \\
\hline Slope Gradient [SL] & $<5$ & 1 & 0,11 & 0,11 \\
\hline \multirow[t]{4}{*}{ (degrees) } & $5-15$ & 2 & & 0,22 \\
\hline & $15-30$ & 3 & & 0,33 \\
\hline & $30-45$ & 4 & & 0,44 \\
\hline & $>45$ & 5 & & 0,55 \\
\hline \multirow[t]{3}{*}{ Thickness of Soils [ToS] } & Deep & 1 & 0,12 & 0,12 \\
\hline & Shallow & 2 & & 0,24 \\
\hline & Bare & 3 & & 0,36 \\
\hline Relative Relief [RR] & $<15$ & 1 & 0,11 & 0,11 \\
\hline \multirow[t]{2}{*}{ (m) } & $15-30$ & 2 & & 0,22 \\
\hline & $>30$ & 3 & & 0,33 \\
\hline Distance to Faults [DiF] & $>200$ & 1 & 0,14 & 0,14 \\
\hline (m) & $\leq 200$ & 2 & & 0,28 \\
\hline Distance to Streams [DiS] & $>50$ & 1 & 0,14 & 0,14 \\
\hline (m) & $\leq 50$ & 2 & & 0,28 \\
\hline Rainfalls [RF] & $0-600$ & 1 & 0,08 & 0,08 \\
\hline \multirow{2}{*}{$(\mathrm{mm})$} & $600-800$ & 2 & & 0,16 \\
\hline & $>800$ & 3 & & 0,24 \\
\hline \multirow[t]{9}{*}{ Slope Aspect [ASP] } & flats & 1 & 0,07 & 0,07 \\
\hline & $\mathrm{N}$ (facing slopes) & 3 & & 0,21 \\
\hline & $\mathrm{NE}$ & 3 & & 0,21 \\
\hline & $\mathrm{E}$ & 1 & & 0,07 \\
\hline & SE & 1 & & 0,07 \\
\hline & $\mathrm{S}$ & 1 & & 0,07 \\
\hline & SW & 2 & & 0,14 \\
\hline & W & 1 & & 0,07 \\
\hline & NW & 2 & & 0,14 \\
\hline Curvature [CUR] & $>0$ & 1 & 0,03 & 0,03 \\
\hline \multirow[t]{4}{*}{$\left(m^{-1}\right)$} & $=0$ & 2 & & 0,06 \\
\hline & $-0,5-0$ & 3 & & 0,09 \\
\hline & $-1,6--0,5$ & 4 & & 0,12 \\
\hline & $<-1,6$ & 5 & & 0,15 \\
\hline
\end{tabular}


Each of the data layers was grouped into various classes and each class was assigned a rate. Rating of individual classes denotes the degree of susceptibility they represent. The distribution of values within each data layers was taken into consideration for the differentiation of the classes. Classification values from studies at different areas of the world were found not to be applicable in this specific case. Previous statistical studies though offer complementary information regarding the actual behaviors of various factors (Koukis et al. 1994, Nikolaou et al. 1997).

According to their relative importance to slope instability in the study area, the various classes of different data layers were assigned weights between 0,0 and 1,0 (collectively adding to 1,0). The significance of each class towards the occurrence of landsliding is obtained by multiplying its weights and its class rate.

Whilst literature was consulted (Koukis \& Ziourkas 1991, Koukis et al. 1994, Nikolaou 1997), it was ultimately through field observation and experience that the weighting system was decided upon. Establishment of weights for variables was somewhat arbitrary, as long as relative rather than absolute landslide susceptibility estimation is attempted. The final weights adopted after the optimizations of the susceptibility map by repeated examination of the combination of various factors are tabulated in (Tab. 1).

\section{SUSCEPTIBILITY POTENTIAL INDEX - SPI}

The overall susceptibility was calculated as an index named SPI (Susceptibility Potential Index), expressing the combination of the different weighted layers into a single map using a certain combination rule,

$$
\mathrm{SPI}=\Sigma \text { (weights } \times \text { layer attribute) } / \text { number of data layers }
$$

Note that 'layer attribute' refers to the rate assigned to the various classes and the 'number of data layers' to the total number of factors (constant $=10$ ) selected for landslide susceptibility zonation. Reclassification of susceptibility scores based on natural breaks in the cumulative frequency histogram of SPI values (Fig. 3) was used to delineate various susceptibility zones namely, very high, high, moderate, low and very low (Fig. 4).

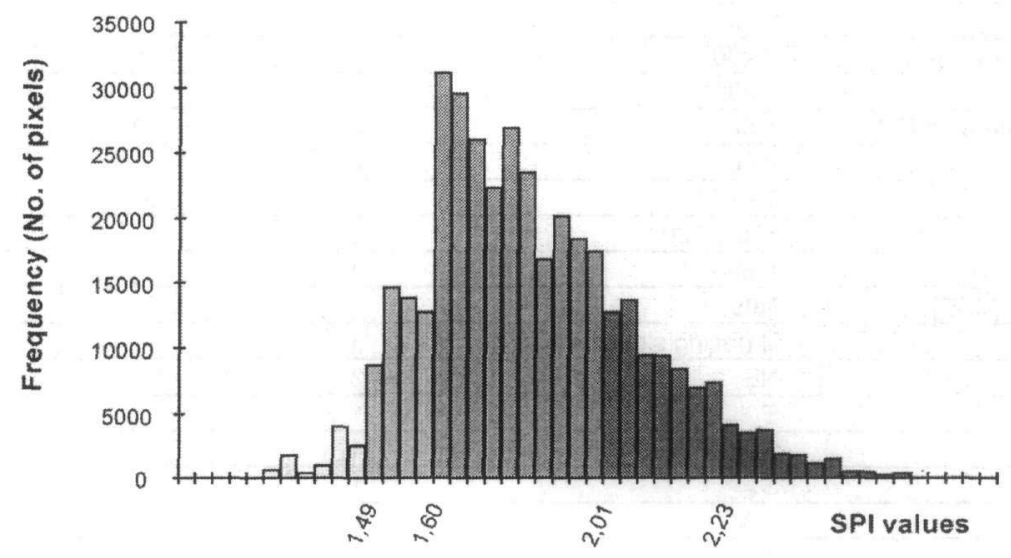

Figure 3. Frequency histogram of SPI values in the study area. The classes were separated by Jerk's method. 


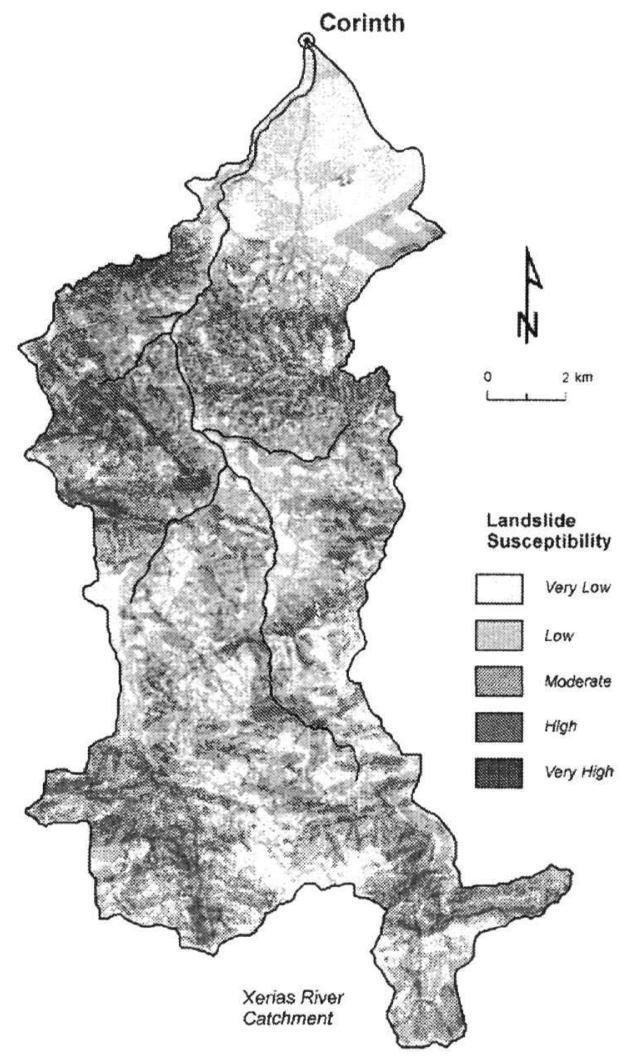

Figure 4. Landslide susceptibility map by reclassification of the estimated values of SPI into five categories of potential susceptibility. independent variables that reflect conditions prior to slope movements should be addressed, condition which is not always ensured in statistical techniques.

The criticism relating the subjectivity of qualitative methodologies is not necessarily bad, considering that it is based on the opinion of the expert. Establishment of weights for variables was somewhat arbitrary, as long as relative rather than absolute landslide susceptibility estimation is attempted. Taking into account previous statistical techniques as complementary information to rank factors and not as a basis to establish the weighting system, allowed the reconsideration in some cases of the weights given. The quality of the final product - landslide susceptibility map - at this specific scale was examined by overlaying susceptibility map and landslide inventory data for field observation. As far as the verification of the method used showed satisfactory results, this type of studies will provide a numerical basis for exploring landslide susceptibility in the future. The scale of the final map (1:50.000) is strictly depended on the scale of the data used for its generation.

\section{REFERENCES}

Abalagan, R., 1992. Landslide hazard evaluation and zonation mapping in mountainous terrain. Engineering Geology, 32, 269-277.

Atkinson, P.M., Massari, R., 1998. Generalized linear modeling of susceptibility to landsliding in the Central Apennies. Italy. Computers and Geosciences, 24(4), 373-385. 
Bannert, D., 1981. Geological map of Greece, Ligourion sheet, scale 1:50000, IGME publications.

Bornavas, J., Lalechos, N., Fillipakis, N., 1971. Geological map of Greece, Korinthos sheet, scale 1:50000, IGME publications.

Carper, W.J., Lillesand, T.M., Kiefer, R.W., 1990. The use of intensity-hue-saturation transformation for merging SPOT panchromatic and multispectral image data. Photogrammetric Engineering \& Remote Sensing, 56(4), 459-467.

Carrara, A., Cardinali, M., Detti, R., Guzzetti, F., Pasqui, V., Reichenbach, P., 1991. GIS techniques and statistical models in evaluating landslide hazard. Earth Surface Processes and Landforms, 16(5), 427-445.

Carrara, A., Cardinali, Guzzetti, F., Reichenbach, P. 1995. GIS-based techniques for mapping landslide hazard. In: Carrara, A., Guzzetti, F., (eds) Geographical information systems in assessing natural hazards. Kluwer, Dordrecht, 135-176.

Donati, L., Turrini, M.C., 2002. An objective method to rank the importance of factors predisposing to landslides with the GIS mothodology: application to an area of the Apennines (Valnerina; Perugia, Italy). Engineering Geology, 63, 277-289.

ERDAS Inc, 2002. ERDAS IMAGINE Field Guide. Leica Geosystems, GIS \& Mapping division, Atlanda, USA, $659 \mathrm{p}$.

Gaitanakis, P. Mettos, A., Fytikas, M., 1985. Geological map of Greece, Sofikon sheet, scale 1:50000, IGME publications.

Gokceoglu, C., Aksoy, H., 1996. Landslide susceptibility mapping of the slopes in the residual soils of the Mengen region (Turkey) by deterministic stability analyses and image processing techniques. Engineering Geology, 44, 147-161.

Guzzetti, F., Carrara, A., Cardinali, M., Reichenbach, P., 1999. Landslide hazard evaluation: a review of current techniques and their application in multi-scale study, central Italy. Geomorphology, 31, 181-216

Horn, B.K.P., 1981. Hill shading and reflectance map. IEEE, 69(1), 14-47.

Koukis, G., Ziourkas, C., 1991. Slope instability phenomena in Greece: A statistical analysis, Bulletin of Intnational Association of Engineering Geologists, 43, 47-60.

Koukis, G., Fsiambaos, G., Sabatakakis, N., 1994. Slope movements in the Greek territory: A statistical approach. 7th Int. IAEG Congress, Lisbon, vol. VI, 4621-4628.

Lakaphossi, A., Ziangas, E., Nakos, G., 1987. Soil map of Greece, Korinthos sheet, scale 1:50000, Ministry of Agriculture, Forest Service publications.

Lee, S, Min, K., 2001. Statistical analysis of landslide susceptibility at Yongin, Korea. Environmental Geology, 40, 1095-1113.

Nikolaou, N., 1997. Rain and landslide manifestation correlation in Korinthos country, Greece. Inter. Symposioum on Engineering Geology and the Environment, Athens, 1, 919-924.

Pachauri, A. K., Gupta, P. V., Chander, R, 1998. Landslide zoning in a part of the Garhwal Himalayas. Environmental Geology, 36(3-4), 325-334.

Saha, A.K., Gupta, R.P., Arora, M.K., 2002. GIS-based landslide hazard zonation in the Bhagirathi (Ganga) Valley, Himalayas. International Journal of Remote Sensing, 23(2), 357-369.

Schinas, K., Ziangas, E, Nakos, G., 1987. Soil map of Greece, Ligourion sheet, scale 1:50000, Ministry of Agriculture, Forest Service publications.

Singh, V.P., 1989. Hydrologic Systems, Watershed Modeling. vol. II, Prentice-Hall, New Jersey, 320p.

Tataris, A., Kallergis, G., Kounis, G., 1970. Geological map of Greece, Nafplion sheet, scale 1:50000, IGME publications.

van Westen, C.J., Seijmonsbergen, A.C. \& Mantovani, F., 1999. Comparing landslides hazard maps. Natural Hazards, 20 (2/3), 137-158.

Vardakis, G., Ziangas, E., Nakos, G., 1985. Soil map of Greece, Sofikon sheet, scale 1:50000, Ministry of Agriculture, Forest Service publications.

Vardakis, G., Ziangas, E., Nakos, G., 1988. Soil map of Greece, Nafplion sheet, scale 1:50000, Ministry of Agriculture, Forest Service publications.

Varnes, D.J., 1984. Landslide hazard zonation: a review of principles and practice. Commission on landslides on the IAEG, UNESCO, Natural Hazards no.3, 61pp.

Zevenbergen, L.W., Thorne, C., 1987. Quantitative analysis of land surface topography. Earth Surface Processes and Landforms, 12, 47-56. 